\title{
Inducible promoters and functional genomic approaches for the genetic engineering of filamentous fungi
}

\author{
Janina Kluge $^{1}$ • Dominik Terfehr ${ }^{1}$ • Ulrich Kück ${ }^{1}$ \\ Received: 23 March 2018 / Revised: 17 May 2018 / Accepted: 18 May 2018 / Published online: 2 June 2018 \\ (C) The Author(s) 2018
}

\begin{abstract}
In industry, filamentous fungi have a prominent position as producers of economically relevant primary or secondary metabolites. Particularly, the advent of genetic engineering of filamentous fungi has led to a growing number of molecular tools to adopt filamentous fungi for biotechnical applications. Here, we summarize recent developments in fungal biology, where fungal host systems were genetically manipulated for optimal industrial applications. Firstly, available inducible promoter systems depending on carbon sources are mentioned together with various adaptations of the Tet-Off and Tet-On systems for use in different industrial fungal host systems. Subsequently, we summarize representative examples, where diverse expression systems were used for the production of heterologous products, including proteins from mammalian systems. In addition, the progressing usage of genomics and functional genomics data for strain improvement strategies are addressed, for the identification of biosynthesis genes and their related metabolic pathways. Functional genomic data are further used to decipher genomic differences between wild-type and high-production strains, in order to optimize endogenous metabolic pathways that lead to the synthesis of pharmaceutically relevant end products. Lastly, we discuss how molecular data sets can be used to modify products for optimized applications.
\end{abstract}

Keywords Fungal biotechnology $\cdot$ Inducible promoter systems $\cdot$ Heterologous products $\cdot$ Functional genomics $\cdot$ Strain improvement

\section{Introduction}

Filamentous fungi possess a highly important role in pharmaceutical and biotechnical applications. As producers of primary and secondary metabolites, they are economically important for the food, paper, or pharmaceutical industry, among others (Alberti et al. 2017; Dufosse et al. 2014; Kuivanen et al. 2015). In order to obtain strains with an optimal production yield, strain improvement programs were set up to generate randomly mutagenized derivatives that have passed strict selection procedures. With the advent of DNA-mediated transformation systems for filamentous fungi about 40 years ago, in vitro recombinant technologies were invented to genetically manipulate industrial strains (Case et al. 1979; Stahl et al. 1982). While bacterial and yeast expression systems were

Ulrich Kück

ulrich.kueck@rub.de

1 Lehrstuhl für Allgemeine und Molekulare Botanik, Ruhr-University Bochum, Universitätsstr. 150, 44780 Bochum, Germany accompanied by the development of sophisticated gene expression systems in the early studies, filamentous fungi lag behind in providing comparable systems (Alberti et al. 2017). This is in part due to the fact that the expression machinery is more complex in filamentous fungi than in bacteria and yeasts.

As an advantage, filamentous fungi tend to have posttranslational modification systems that allow the production of functional mammalian proteins, which are difficult to perform in bacterial and yeast expression systems in many cases (Ward 2012).

In a recent study, molecular tools, such as homologous recombination and RNA interference systems that are suitable for the genetic manipulation of filamentous fungi were reviewed (Kück and Hoff 2010). Here, we will extend this survey by summarizing the available inducible promoter systems to obtain controlled gene expression in industrial strains. Finally, we focus on representative examples, where filamentous fungi were used for the successful production of heterologous proteins. Nowadays, this is highly influenced by the availability of genomic and functional genomic data sets, 
which are used for novel strategies in strain improvement programs. Another recent valuable tool for directed strain improvement is the CRISPR/Cas9 system, which is suitable for multiple gene editing events. We would like to refer to recently published reviews that cover the development of CRISPR/ Cas9-based gene editing in filamentous fungi (Krappmann 2017; Shi et al. 2017).

\section{Claims and conditions for the application of inducible promoters}

Extensive studies in eukaryotic systems have established the mechanistic key concept of controlled gene regulation (Levine et al. 2014; Soutourina 2017; Spitz and Furlong 2012). The expression of eukaryotic genes is governed primarily at the level of transcriptional initiation, which corresponds to the complex interplay between the promoter, RNA polymerase II, and transcription factors (Sainsbury et al. 2015; Struhl 1987). Promoters are defined as the DNA sequence immediately surrounding the transcription start site, which is bound by the basal transcription machinery, thus allowing transcriptional initiation. Over the years, the knowledge of promoter architecture expanded and led to the development and establishment of constitutive and inducible promoter systems ( $\mathrm{Su}$ et al. 2012; Woo and Li 2011). In Table 1, we list inducible promoter systems that are commonly used in applied research with filamentous fungi. In the following, some of these are described in detail.

Inducible promoters were initially developed to synthesize exactly one additional gene product under precisely defined conditions within a certain time interval. Therefore, these systems find application in the functional characterization of essential genes in the laboratory, as well as in the biotechnological production of heterologous protein products, where a finetunable expression is often desired, especially when the protein is toxic to the cell (Lee et al. 2010; Nevalainen et al. 2005). An ideal inducible promoter is primarily characterized by a strong and tight controllable regulation, a cost-efficient induction, and an effective expression of the gene of interest being placed downstream of the inducible promoter sequence. In general, a distinction takes place between chemically and physiologically induced promoters. Chemically regulated systems are induced or repressed by the presence or absence of chemical compounds, such as alcohols, antibiotics, hormones, or carbon sources (Matsuzawa et al. 2013; Meyer et al. 2011). In contrast, the regulation of physiologically controlled promoters is determined by abiotic environmental factors. In this context, systems were established, whose regulation takes place depending on the osmotic stress, temperature, light, etc. (Fischer et al. 2016; Zhang et al. 2016).

The selection of a suitable promoter system should be specifically adapted to experimental approaches because not every system brings along optimal conditions for the selected model organism. Thus, it must be considered that certain inductive or repressive substances or the produced protein has a toxic effect in some organisms (Kim et al. 2016; Lee et al. 2010). In addition, a leakiness of the promoter, which results in a minimal constitutive activity, leads to uncontrolled gene expression (Meyer et al. 2011). In the subsequent years, several inducible expression systems were discovered and used for applied approaches. Few of them that were used in recent biotechnical applications will be summed up in this review.

\section{Inducible promoters depending on carbon sources}

The glaA promoter of the glucoamylase A gene from Aspergillus niger was one of the first inducible systems, which was commonly used in filamentous fungi. Induction of gla $\mathrm{A}$ promoter-driven gene expression occurs on starch-containing growth media or alternatively on media with maltodextrine, maltose, or glucose. Repression is achieved when strains are grown on xylose-containing minimal media (Siedenberg et al. 1999). In another homologous promoter system, promoter sequences of the glucoamylase gene were fused with the $\beta$ glucosidase gene from A. niger or endoglucanase IV from Trichoderma reesei for the construction of recombinant Penicillium verruculosum strains (Bulakhov et al. 2017). Compared to the wild type, the strain harboring the recombinant promoter displayed a more efficient hydrolysis of a lignocellulosic substrate. In Aspergillus oryzae, the glaA promoter was recently used for the production of L-malate, which is widely utilized in the food and beverage industry as an acidulant and flavor enhancer (Liu et al. 2017b; Thakker et al. 2015). A further improvement of promoter strength was attained when five copies of the -427 to -331 upstream region of glaA carrying at least one CAAT-Box were integrated to efficiently increase Lmalate production directly from corn starch (Liu et al. 2017b). This cis-element arrangement was also shown to improve promoter strength and inducibility of the Trichoderma reesei cbh1and $x y n 1$ promoters. Detailed analysis of the first $850 \mathrm{bp}$ of both promoter sequences identified binding sites for Xyr1 (XBS), the essential transactivator of $c b h 1$ and $x y n 1$ gene expression. In these promoters, 14 and $8 \mathrm{XBS}$, respectively, are arranged in tandem or in the inverted repeat direction. Further improvement of these promoters was obtained when additional XBS were integrated in inverted repeat orientation. In the case of $c b h 1$ promoter, an induction of gene expression by xylan or wheat straw was received by modifying the XBS inverted repeats (Kiesenhofer et al. 2018). Also, in a recent attempt, the cbhI promoter was further improved to control the heterologous expression of two feruloyl esterase genes to produce ferulic acid, a food additive or potential anti-inflammatory therapeutic agent from wheat bran (Long et al. 2018).

Xylose-inducible promoters have been established in some industrial host systems for some time, including the abovementioned $x y n 1$ promoter from $T$. reesei and $x y l P$ from 
Table 1 Inducible promoters in filamentous fungi

\begin{tabular}{|c|c|c|c|c|}
\hline Promoter & Gene product & Induction by/repression by & Donor & Reference \\
\hline alcA & Alcohol dehydrogenase I & Ethanol/glucose & Aspergillus nidulans & Waring et al. (1989) \\
\hline amy $B$ & TAKA-amylase A & Starch or maltose/glucose & Aspergillus oryzae & Tada et al. (1991), Tsuchiya et al. (1992) \\
\hline bli-3 & Blue light-inducible gene & Blue light/darkness & Neurospora crassa & Eberle and Russo (1994) \\
\hline bphA & Benzoate p-hydrolase & $\begin{array}{l}\text { Benzoic acid (benzoate)/deficiency } \\
\text { of benzoate }\end{array}$ & Aspergillus niger & Antunes et al. (2016) \\
\hline$c a t R$ & Catalase & $\mathrm{H}_{2} \mathrm{O}_{2}$ and $\mathrm{CaCO}_{3} /$ n.d. & Aspergillus niger & Sharma et al. (2012) \\
\hline $\operatorname{cbhI}$ & Cellobiohydrolase I & Various saccharides/glucose & Trichoderma reesei & Nyyssönen and Keränen (1995) \\
\hline crel & Glucose repressor & Glucose/deficiency of glucose & $\begin{array}{l}\text { Acremonium } \\
\text { chrysogenum }\end{array}$ & Janus et al. (2008) \\
\hline exylA & Endoxylanase & Xylose/sucrose & Aspergillus awamori & Gouka et al. (1996) \\
\hline gas & 1,3-beta-glucanosyltransferase & Low $\mathrm{pH}$ value $/ \mathrm{pH}>5.0$ & Aspergillus niger & Yin et al. (2017) \\
\hline glaA & Glucoamylase A & Glucose/xylose & Aspergillus niger & Boel et al. (1984) \\
\hline glal & Glucoamylase & Glucose/xylose & Penicillium verruculosum & Bulakhov et al. (2017) \\
\hline mirl & Siderophore transporter & Iron starvation/Iron sufficiency & $\begin{array}{l}\text { Acremonium } \\
\text { chrysogenum }\end{array}$ & Gsaller et al. (2013) \\
\hline niiA & Nitrite reductase & Nitrate/ammonium & Aspergillus oryzae & Müller et al. (2002) \\
\hline$q a-2$ & Catabolic 3-dehydroquinase & $\begin{array}{l}\text { Quinic acid/low quinic acid or high } \\
\text { sugar concentration }\end{array}$ & Neurospora crassa & Giles et al. (1985) \\
\hline Smxyl & Endoxylanase & Xylose/glucose & $\begin{array}{l}\text { Acremonium } \\
\text { chrysogenum }\end{array}$ & Bloemendal et al. (2014) \\
\hline tcu-1 & Copper transporter & Copper depletion/copper availability & Neurospora crassa & Lamb et al. (2013) \\
\hline thiA & Thiamine thiazole synthase & Thiamine/deficiency of thiamine & Aspergillus oryzae & Shoji et al. (2005) \\
\hline$v v d$ & Blue light receptor & Light/darkness & Neurospora crassa & Hurley et al. (2012) \\
\hline$x y l 1$ & Endoxylanase & Xylose (and xylan)/glucose & $\begin{array}{l}\text { Acremonium } \\
\text { chrysogenum }\end{array}$ & Blatzer et al. (2014) \\
\hline$x y l P$ & Endoxylanase & Xylose (and xylan)/glucose & Penicillium chrysogenum & Zadra et al. (2000) \\
\hline xyn 1 & Endoxylanase & $\begin{array}{l}\text { Low concentration of xylose/high } \\
\text { concentration of xylose }\end{array}$ & Trichoderma reesei & Mach et al. (1996) \\
\hline$z e a R$ & Transcription factor & $\begin{array}{l}\text { Zearalenone/Deficiency of } \\
\text { zearalenone }\end{array}$ & Fusarium grainearum & Lee et al. (2010) \\
\hline
\end{tabular}

Penicillium chrysogenum (Zadra et al. 2000). Interestingly, the latter was proven to be functional in other filamentous fungi from the order Sordariomycetes (Bloemendal et al. 2014; Kopke et al. 2010). This includes the well-established $\beta$-lactam producer Acremonium chrysogenum for which three controllable promoter systems were developed in recent years. One is the mirl promoter, encompassing a 1700-bp region upstream of a siderophore transporter gene, which was shown to induce $g f p$ gene expression during iron starvation, while iron sufficiency results in repression (Gsaller et al. 2013). Two other inducible promoters stem from the xylanase genes from Sordaria macrospora and A. chrysogenum and drive gene expression on xylose-containing media. On the contrary, glucose results in gene repression. Both promoters are very effective in A. chrysogenum and contribute to the rather limited number of molecular tools for this highly important industrial fungus. Furthermore, the $S m x y l$ promoter was successfully used for the application of a one-step FLP/FRT recombination system in order to construct marker-free transgenic strains (Blatzer et al. 2014; Bloemendal et al. 2014).

\section{Metabolism-independent inducible promoter systems}

A few years ago, the thiamine-regulatable thiA promoter was established for A. oryzae. The expression level of this promoter was controlled by the concentration of external thiamine in the media. This promoter was recently used in an interesting approach, where autophagy-related genes were shown to affect the heterologous expression of the bovine chymosin gene in $A$. oryzae. The transformation of $A$. oryzae strains, lacking autophagy genes Aoatg1, Aoatg13, Aoatg4, Aoatg8, or Aoatg 15 with a bovine chymosin (CHY) expression construct resulted in a threefold enhanced production level of $\mathrm{CHY}$ in comparison to the control strain. However, conidiation was significantly reduced in these strains. Since huge amounts of conidia are necessary for the inoculation of large-scale cultures, gene-conditional expression strains of four Aoatg genes were constructed in which the promoter region of the corresponding genes was substituted by the thiA promoter. Conidiation was clearly increased in the absence of thiamine, whereas autophagy was still repressed under growth 
conditions with thiamine. Nevertheless, the production level of CHY was comparable to that of the $\Delta$ Aoatg strains (Yoon et al. 2013). The fact that thiamine content does not alter fungal morphology makes the thiA promoter a useful alternative to conventionally used promoters. For example, alcA and $a m y B$ promoters depend on the available carbon sources, which might have an impact on fungal physiology or morphology (Shoji et al. 2005). In submerged cultures from A. nidulans, expression of the abaA gene under the control of the alcA promoter resulted in vacuolated hyphae with abnormal septation (Mirabito et al. 1989). A comparable effect was observed when a copper-inducible promoter was used for heterologous expression since copper has physiological and toxic effects on fungal growth and development (Lee et al. 2010).

A completely new promoter system was established for $A$. niger. This was adapted by the medium conditions of citric acid fermentation. During this process, the $\mathrm{pH}$ of the growth medium decreased from 5.0 below 2.0 and was nearly consistent at a value below 2.0 in later cultivation phases. Therefore, a pH-responsive promoter, Pgas, which efficiently enhances gene expression at $\mathrm{pH} 2.0$, was developed for dynamic metabolic engineering. The gas gene was found in an expression data-set and encodes the 1,3- $\beta$-glucanosyltransferase GelD, which is necessary for maintenance of the fungal cell wall due to the synthesis of glucan. This study showed that Pgas is tightly expressed at $\mathrm{pH}$ 2.0. In terms of promoter strength, Pgas is comparable to PgpdA. Furthermore, the promoter strength varied by using different types of acids. While induction was strictly $\mathrm{pH}$ dependent, promoter strength was higher using organic acids compared to inorganic acids. Pgas was used to express the cis-aconitate decarboxylase $(C A D)$ gene from Aspergillus terreus in A. niger. Due to the fact that $A$. niger produces large amounts of citrate $(180 \mathrm{~g} / \mathrm{l})$, which is the precursor of itaconate, the aim was to modify the natural citrate producer into an itaconate producer. Itaconic acid is an unsaturated dicarbonic acid with a high industrial potential because it can be used as a monomer for the production of a plethora of products including resins, plastics, paints, and synthetic fibers. Since constitutive expression of the $C A D$ gene resulted in only a small yield of itaconate, the use of the Pgas promoter led to a gradually increased expression level of $C A D$ parallel to a decreasing $\mathrm{pH}$ value. Finally, a titer of $5 \mathrm{~g} / \mathrm{l}$ was obtained, which was fivefold higher than comparable experiments in which the PgpdA promoter was used to drive expression of the $C A D$ gene (Yin et al. 2017).

\section{Adaption of the Tet system for eukaryotes}

Another frequently used expression mechanism, which was originally identified in Escherichia coli is the tetracycline (tc) expression system (Tet system). The central components of this system stem from the Tn10 tetracycline resistance operon. In Gram-negative bacteria, the membrane-residing TetA protein is responsible for an antiport of tc, which leads to resistance to this antibiotic. The tetA gene is under the transcriptional control of the tc-dependent Tet repressor (TetR), which negatively controls tc resistance. In the absence of tc, TetR binds to the tet operator (tetO) resulting in a transcriptional shutdown of the operon. In contrast, in the presence of tc, the interaction between the repressor and the operator is efficiently prevented, leading to a dissociation of TetR from tetO. For use in eukaryotic organisms, the modification of regulatory elements was necessary and a differentiation between a Tet-On and the Tet-Off system was made. Transgenic mice were the first eukaryotes in which Tet-Off was established (Gossen and Bujard 1992). A tc-dependent transactivator (tTA) was generated by the fusion of TetR with the transcriptional activator domain from herpes simplex virus protein 16 (VP16). By the addition of tc or its analog doxycycline (Dox), tTA cannot specifically bind to tetO; thus, transcription of the gene of interest is disrupted (Tet-Off state) (Fig. 1a). In contrast, for the Tet-On system, a reverse hybrid tTA (rtTA) was constructed, which, in the presence of tc or Dox, functions as an activator of gene expression. The insertion of additional mutations resulted in the reverse hybrid transactivator $\mathrm{rtTA}_{2} \mathrm{~S}-\mathrm{M} 2$ to increase the rtTA binding sensitivity to Dox and the expression level of rtTA in eukaryotes. An improvement of the tetracycline-responsive promoter was achieved by the insertion of seven copies of the tetO sequence (tetO7) upstream of a minimal promoter Pmin (Fig. 2a, b).

\section{Previous and recent applications of the Tet system}

Previously, the Tet-On/Tet-Off system was shown to be functional in Aspergillus fumigatus (Vogt et al. 2005). In this study, three plasmids were constructed, one harboring the expression cassette consisting of the transactivator $\mathrm{rtTA}_{2}{ }^{\mathrm{S}}-\mathrm{M} 2$ under the control of the constitutive $g p d A$ promoter (PgpdA::rtTA2 $2^{\mathrm{s}}$ M2), the other comprising PgpdA::tTA, and the third one with a tetO7 sequence linked to a minimal promoter sequence of PgpdA upstream of an E. coli hygromycin resistance gene (tetO7::Pmin::hyg ${ }^{\mathrm{R}}$ ). The corresponding plasmid pairs were transferred in parallel into a single A. fumigatus strain and hygromycin-resistant transformants were obtained in the presence and absence of Dox indicating that the Tet system functions in A. fumigatus. However, the tightness of the system was not examined in detail. Especially the Tet-On system was further developed for an application in A. niger. It was also established as a metabolism-independent gene expression system in this study, but all components of the Tet-On system were combined on one plasmid. For testing its functionality, a minimal gpdA promoter, which was fused to the tetO7 sequence, was used to control luciferase gene expression. While in the absence of Dox no luminescence was detectable, the presence of Dox led to the induction of luciferase gene expression. It was clearly shown that the system is tight, 
a
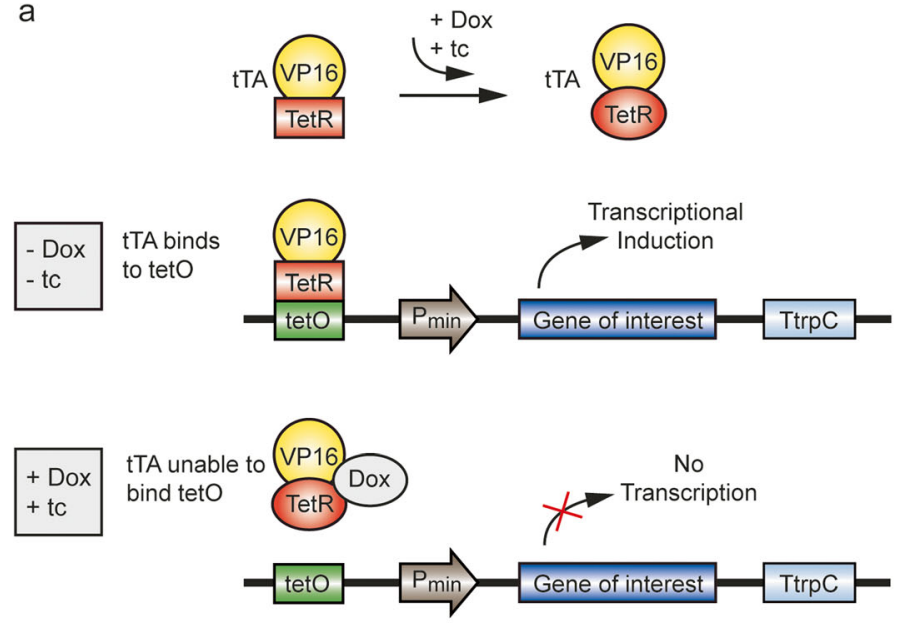

b
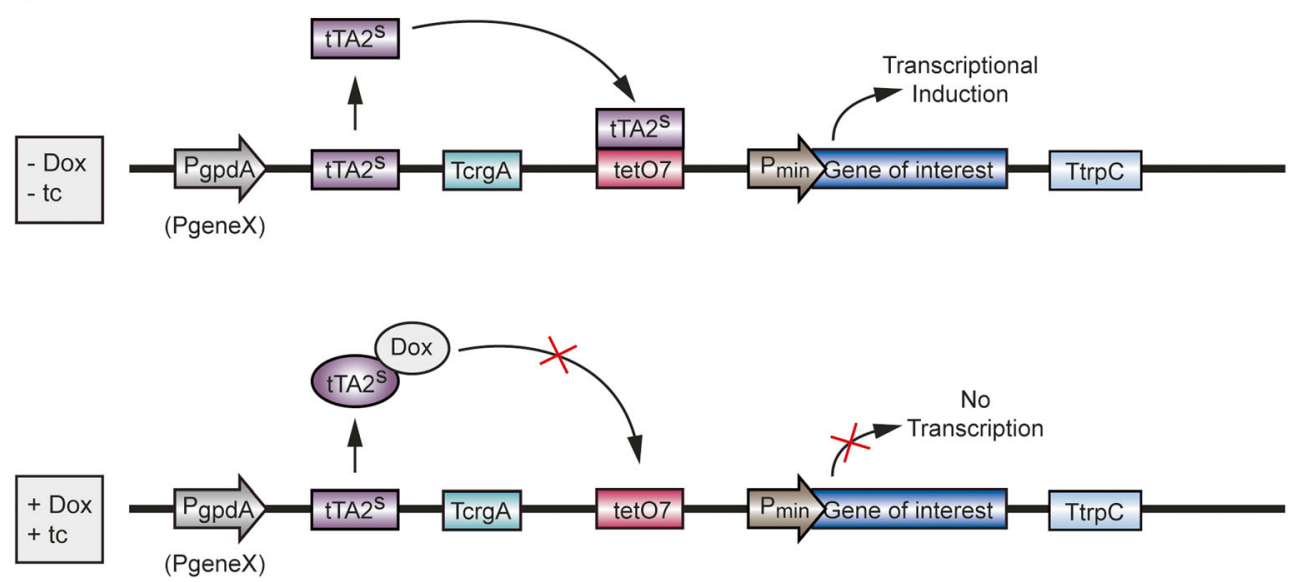

Fig. 1 Tet-Off expression system. a Basic version of the Tet-Off expression system in eukaryotes. The fusion of TetR with VP16 leads to the generation of the tetracyclin-dependent transactivator tTA. When tetracycline or its analog doxycycline is added, tTA is unable to specifically bind to tetO due to a conformational change. As a result, transcription of the gene of interest, which is controlled by Pmin, is disrupted. Thus, transcriptional activation takes place in the absence of tetracycline or doxycycline. Addition of the either drug leads to transcriptional shutdown. Dox, doxycycline; VP16, transcriptional activator domain from herpes simplex virus; tc, tetracycline; TetR, tetracycline-dependent Tet repressor; tetO; tetracycline operator sequence; tTA, tetracyclin-dependent transactivator; TtrpC, trpC terminator from Aspergillus nidulans; Pmin, minimal promoter. b Optimized module of the Tet-Off expression system for A. niger. The transactivator tTA2 ${ }^{\mathrm{S}}$, optimized for mammals, was used downstream of P $g p d A$ promoter. The promoter can be selected individually

induction takes place immediately after addition of the inducer, and fine-tuning of the system is achieved by inducer concentration and gene copy number (Meyer et al. 2011).

In recent years, the Tet system was also used for the controlled expression of secondary metabolite clusters, such as silent gene clusters in Aspergilli. In A. fumigatus strains grown under induced conditions, the Tet-On overexpression of a putative transcription factor resulted in the activation of a secondary metabolite cluster, which led to the biosynthesis of 5- depending on the model organism (PgeneX). Seven copies of tetO sequence were inserted (tetO7) upstream of a minimal promoter in order to increase tTA $2^{\mathrm{S}}$ binding. In the absence of tetracycline or its analog doxycycline tTA $2^{\mathrm{S}}$ is able to specifically bind tetO7. Thus, the transcriptional induction of the gene of interest, which is controlled by Pmin takes place. Addition of drug leads to transcriptional shutdown. For further details, see text. Abbreviations: Dox, doxycycline; VP16, transcriptional activator domain from herpes simplex virus tc, tetracycline; TetR, tetracycline-dependent Tet repressor; tetO, tetracycline operator sequence; tetO7, seven copies of tetracycline operator sequence; tTA, tetracyclin-dependent transactivator; $\mathrm{tTA} 2^{\mathrm{S}}$, mammalian tetracyclin-dependent transactivator; T $\operatorname{crg} A, \operatorname{crg} A$ terminator from Aspergillus fumigatus; TtrpC, $\operatorname{trp} C$ terminator from Aspergillus nidulans; Pmin, minimal promoter (adopted from Brockamp et al. 2002, Wanka et al. 2016)

benzyl-1H-pyrrole-2-carboxylic acid, an unknown novel natural compound, named fumipyrrole (Macheleidt et al. 2015). In A. niger, the Tet-On system was used successfully for the expression of polycistronic genes from the Asp-melanin biosynthetic pathway from Aspergillus terreus (Geib and Brock 2017). This is a further good example that the expression genes from secondary metabolite clusters can be tightly expressed in heterologous hosts. Another remarkable example was reported recently for the rice pathogen Fusarium 
a
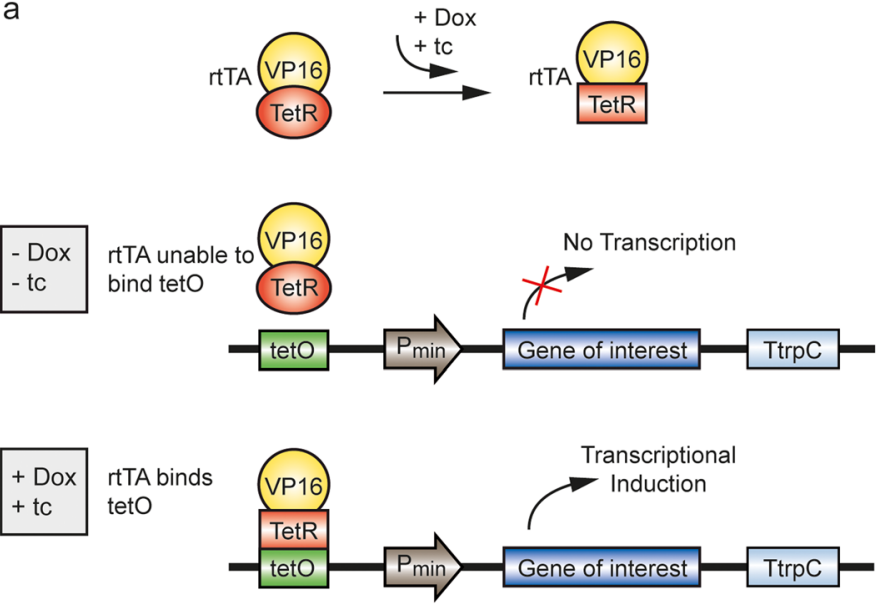

b
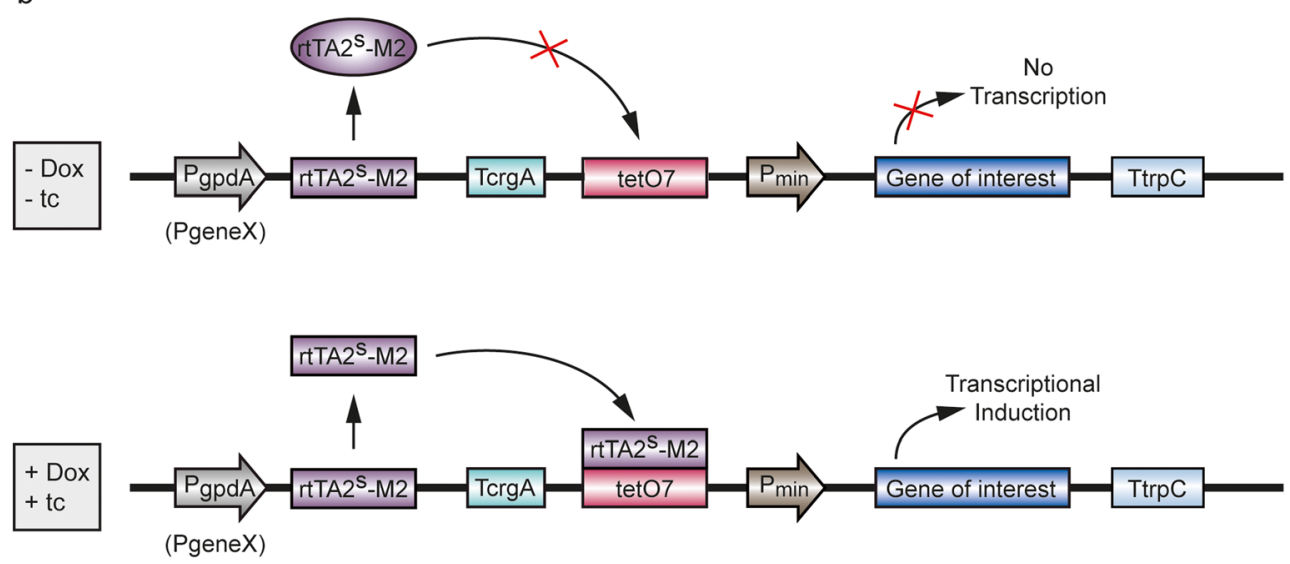

Fig. 2 Tet-On expression system. a Basic version of the Tet-On expression system in eukaryotes. The rtTA fusion protein comprises of TetR and VP16 activation domain. A four amino acid change in the TetR DNA binding motif alters rtTA's binding characteristics, such that it can only recognize tetO sequence in the presence of tetracycline or its analog doxycycline. Thus transcriptional induction of the gene of interest, which is controlled by a minimal promoter, takes place. b Optimized version of the Tet-On expression system for A. niger. The insertion of additional mutations resulted in the reverse hybrid transactivator $\mathrm{rtTA} 2^{\mathrm{S}}-\mathrm{M} 2$, which is controlled by the PgpdA promoter,

fujikuroi. In this fungus, constitutive overexpression of the transcription factor TF22 drives the activation of the complete trichosetin gene cluster. Trichosetin is a PKS-NRPS-derived tetramic acid possessing biological activity against a broad range of organisms, encompassing plants and bacteria. Constitutive overexpression resulted in severe growth reduction. To circumvent this undesired morphological defect, the Tet-On system from A. niger was established for F. fujikuroi to obtain the controlled production of trichosetin for further the functional characterization of each gene within the trichosetin cluster (Janevska et al. 2017). One part of the Tet construct contains the already described transactivator rtTA2 ${ }^{\mathrm{S}}-\mathrm{M} 2$ under the control of the constitutive PoliC promoter from $A$. nidulans, while the other part encompasses the $\mathrm{rtTA}_{2}{ }^{\mathrm{S}}-\mathrm{M} 2-$ dependent promoter in front of TF22. The pTET::TF22 to increase the rtTA binding sensitivity and the expression level of rtTA. The used promoter can be selected individually depending on the model organism (PgeneX). An improvement of tetO was achieved by the insertion of seven copies of tetO sequence (tetO7) upstream of the minimal promoter. In the presence of tetracycline or its analog doxycycline, rtTA2 $2^{\mathrm{S}}-\mathrm{M} 2$ is able to specifically bind tetO7 in order to induce the transcription of the selected gene of interest. For further details, see text. Abbreviations: $\mathrm{rtTA}_{2} \mathrm{~S}^{-\mathrm{M} 2}$, mutated reverse hybrid transactivator. All other abbreviations are given in the legend of Fig. 1. (adopted from Brockamp et al. 2002, Wanka et al. 2016)

plasmid was integrated into the wild type and five mutants, carrying deletions of different cluster genes. All transformants showed a strong activity of TF22 expression dependent on the added Dox concentration. However, a leakiness of the system was observed because TF22 showed a basal expression without adding the inducer. As this background expression did not drive activation of the gene cluster, the Tet-On system was suitable as a controllable induction tool. The inducible overexpression of TF22 results in activation of the three cluster genes indicating that this transcription factor directs the biosynthesis of trichosetin.

Optimization of the Tet-Off system in A. niger was achieved by using the present plasmid for the Tet-On system and the reverse transactivator $\mathrm{rtTA}_{2}{ }^{\mathrm{S}}-\mathrm{M} 2$ against the $\mathrm{tTAS}^{2}$ transactivator was exchanged, which is optimized for 
mammals, in order to construct a functional Tet-Off cassette (Fig. 1b) (Wanka et al. 2016). Strains with a single copy of the modulated Tet-Off showed a strong luciferase activity, whereas the addition of different Dox concentrations resulted in a downregulation of the luciferase gene expression. However, during the establishment of Tet-Off, it was apparent that not all A. niger transformants containing the Tet-Off construct show a luciferase downregulation after induction. Additionally, most of the transformants lost the Tet-Off cassette during storage on minimal medium. Genetic analysis of the transformants detected 176 bp sequence homology between the minimal gpdA promoter and the constitutive $g p d A$ promoter and this resulted in intra-molecular recombinations and loss of function. Thus, constitutive PgpdA was replaced by the endogenous promoter of the fraA gene, encoding a putative ribosomal subunit. Using the PfraA Tet-Off system, genetically stable transformants were generated, and, in the presence of Dox, a rapid reduction in reporter luminescence was observed. In order to demonstrate a putative application for the characterization of industrially relevant genes, the luciferase reporter gene was substituted by the $g f a A$ gene, which encodes a glutamine:fructose-6-phosphate aminotransferase. This enzyme is involved in the first step of chitin synthesis and chitin synthesis-defective strains cannot grow on media without the supplementation of glucosamine. The functionality of $\mathrm{P} f \mathrm{raA}$ Tet-Off system- $g f a A$ fusion was finally demonstrated when a gfaA-deficient strain was transformed with this construct. In the presence and absence of both Dox and glucosamine in the media, transformants are viable. However, the sole induction of the PfraA Tet-Off system by Dox, in the absence of glucosamine, results in the lethality of transformants. Thus, this system seems to be broadly suitable for industrial application (Wanka et al. 2016). Very recently, the Tet expression system was used to characterize genes that are involved in the viability of A. fumigatus during the infection process in order to identify new antifungal drug targets. For an in vivo approach, a Tet-Off system was designed where the presence of Dox resulted in the downregulation of gene expression. As potential target genes, those for inosine 5'-monophosphate dehydrogenase $(I M P D H)$, which catalyzed the first step in de novo guanine biosynthesis, and L-ornithine $\mathrm{N}^{5}$-oxygenase ( $\operatorname{sidA}$ ), catalyzing the initial step of siderophore biosynthesis, were tested in a murine invasive pulmonary aspergillosis model. The immunosuppression of mice was induced by injection of cyclophosphamide for 4 days and 1 day before inoculation and injection of cortisone acetate 1 day before inoculation. On inoculation day, $40 \mu \mathrm{l}$ of a fresh A. fumigatus conidia suspension was intranasally inoculated under anesthesia. The addition of $200 \mu \mathrm{l}$ Dox $(10 \mathrm{mg} / \mathrm{ml})$ was carried out twice a day by gastric lavage. The downregulation of impdh resulted in reduced virulence in vivo, while switching off the gene expression of sidA led to the generation of avirulent A. fumigatus strains. Additionally, a time-dependent control of sidA expression was verified and the timing of Dox supplementation dramatically impaired the survival rate of mice. This study provides evidence that the Tet-Off system is used to identify genes required for fungal growth within the host following the initiation of infection (Peng et al. 2018).

\section{Production of heterologous products}

Filamentous fungi are often used to produce endogenous compounds which are generated during the primary or secondary metabolism. Often, these enzymes are active within distinct metabolic pathways. Primary metabolites such as organic acids are used in diverse industrial applications. For example, citric, gluconic, fumaric, koji, lactic, and itaconic acids are valuable byproducts that are used in the chemical or food industry (Becker et al. 2015). Citric acid is within these fungal organic acids, the one with the highest yearly production yield (1.75 million tons), and has a market value of US $\$ 1.6$ billion (Demain 2007). Besides organic acids, vitamins are important metabolites, which are produced with the help of filamentous fungi, e.g., Ashbya gossypii produces riboflavin (vitamin B2) at a yield of $20 \mathrm{~g} / \mathrm{l}$. In addition to primary metabolites, filamentous fungi are potent producers of enzymes of which about 100 are used for industrial applications. Most of these enzymes show a hydrolytic activity, such as amylases, proteases, lipases, xylanases, or catalases and are mostly used for the degradation of organic material. Amylases have the highest importance in this context, with an annual production of 95,000 tons and a market value of US $\$ 2.5$ billion (Demain and Vaishnav 2009). Many of these enzymes are heterologously produced in diverse microbial host systems to circumvent difficulties in the cultivation and genetic manipulation of exotic microbes (Schmidt-Dannert 2015). Many fungal enzymes are synthesized in heterologous fungal host that are already established as industrial producers for a wide range of different enzymes or primary- and secondary metabolites. A list of commercial enzymes produced using filamentous fungi can be found at the Association of Manufacturers and Formulators of Enzyme Products (AMFEP, www.amfep.org). Fungi usually have a high secretion capacity and many production strains have a GRAS (generally recognized as safe) status. Furthermore, the post-translational modification of proteins is distinct in eukaryotic and prokaryotic host systems. Established fungal host systems that are amendable for genetic manipulation and with a GRAS status are A. niger, A. oryzae, and T. reesei (Schmidt 2006; Sharma et al. 2009). Therefore, filamentous fungi were used in several efforts for the production of mammalian enzymes and proteins. Particularly, the post-translational modification in eukaryotic microbes has supported attempts to obtain functional proteins from fungal hosts. The first successful approaches with filamentous fungi demonstrated the production of chymosin and 
lactoferrin (Archer 2000). Chymosin from calf vells is used in the food industry for the production of cheese, while lactoferrin, a multifunctional transferrin from cow's milk, has an anti-inflammatory activity. Meanwhile, yeast expression systems have been shown to be superior for the biotechnical production of mammalian proteins with pharmaceutical relevance. Most common host organisms are Saccharomyces cerevisiae, Pichia pastoris, and Hansenula polymorpha (Ganeva et al. 2017; Mallu et al. 2016; Shibui et al. 2013). Nevertheless, filamentous fungi are still used for the heterologous production of different mammalian proteins, for example, the human hormone peptide obestatin was successfully produced using recombinant $T$. reesei strains (Sun et al. 2016). Recently, two fusion proteins each consisting of a highly antigenic protein from Leishmania sp., an antibody specific for a receptor of dendritic cells, and a fragment of native glucoamylase A were generated in A. niger (Magana-Ortiz et al. 2018). Both recombinant proteins may be used for immunization against Leishmaniasis and point to the potential of filamentous fungi as hosts for the generation of pharmaceutically relevant peptides. In this context, it has to be mentioned that well-established organisms with beneficial traits are redeveloped for recombinant protein production. Neurospora crassa is a model organism with suitable traits for heterologous production but has not widely been used for industrial applications. In order to evaluate the usability of $N$. crassa as a host system, the biosynthesis of the human antibody fragment HT186-D11 was tested and production yields of about $3 \mathrm{mg} / \mathrm{L}$ were achieved (Havlik et al. 2017). Although the achieved yields cannot compete with established production hosts like $P$. pastoris, which is able to produce up to 100 -fold higher yields, $N$. crassa seems to be a promising new host system for the production and secretion of heterologous proteins.

\section{Strain improvement using genomics and functional genomics}

The strain improvement programs of $A$. chrysogenum, $P$. chrysogenum, and T. reesei are suitable examples for the efficiency of classical strain improvement by random mutagenesis (Hu and Zhu 2016; Peterson and Nevalainen 2012). However, the random introduction of point mutations also has disadvantages. Improved production strains can acquire point mutations over several rounds of random mutagenesis leading to a reduced growth rate, sporulation defects or genomic instability (Künkel et al. 1992; Lein 1986). In this context, directed genome manipulation can help to overcome the effect of deleterious point mutations. However, an essential prerequisite for this approach is the knowledge of the genome sequence, the encoded genes and the derived metabolic pathways. Therefore, functional genome analysis is an important tool with which to obtain the required information. Within functional genome analysis, the large data amounts of data from different high-throughput techniques are used to assign gene functions with the overall goal of analyzing the relation between the genotype and phenotype of an organism on a genome-wide level.

The still-progressing development of the next-generation sequencing techniques allows a fast and low-cost effective sequencing of complete fungal genomes for which the costs were reduced by a factor of about 50,000 (Goodwin et al. 2016). In parallel, efficient sequencing techniques have increased the output of sequences per run by a factor of 100 to 1000. The newest sequencing platforms, such as Pacific Biosciences (PacBio) or Oxford Nanopore Technologies (ONT), provide continuous sequences with a size of up to $200 \mathrm{~kb}$. This is of major importance when repetitive regions carrying telomers or centromeres have to be sequenced. Currently, about 2700 genomes of fungal species are published and are represented, for example, in the 1000 Fungal Genome Project (http://1000.fungalgenomes.org/home/). The sequenced genomes possess a large number of uncharacterized genes, whose functions can be sometimes deduced from orthologous sequences known from other species. Valuable classification libraries to evaluate the function of proteins include the Functional Catalogue (FunCat), Gene Ontology (GO), or the Kyoto Encyclopedia of Genes and Genomes (KEGG) (Rüpp et al. 2004, Ashburner et al. 2000, Karnehieser and Goto 2000). A common characteristic of these databases is that classifications of genes are done on the basis of hierarchical structures, in which major categories are split up into sub-categories. Each sub-category provides more precise information, e.g., about the cellular function of the protein. An alternative approach in predicting the function of an unknown protein is the use of conserved protein domains for a homology-based search. These domains can be used to search against databases like Protein families (Pfam), Clusters of Orthologous Groups of proteins (COGs), and The Institute for Genomic Research's database of protein families (TIGRFAM) to identify other proteins with similar domains or domain structure and to predict protein functions (Finn et al. 2016; Galperin et al. 2015; Haft et al. 2003). With this kind of homology-based functional analysis, even genomes of uncharacterized organisms, metagenomes, and metatranscriptomes can be analyzed. Representative examples from the field of filamentous fungi are the genomes from Lichtheimia corymbifera, a member of the basal Mucorales, or various Penicillium species (Lessard et al. 2014; Nielsen et al. 2017; Schwartze et al. 2014). The genome sequences from 24 Penicillium species revealed that a total of 1317 putative biosynthetic gene clusters exist. This survey indicates the potential of natural products that can be synthesized by members of this genus (Nielsen et al. 2017). After identification, interesting genes or even whole gene clusters can be expressed heterologously in suitable host systems (Bok et al. 2015). 
Similar to metagenomes, which are generated by using total DNA from the sample for high throughput sequencing, metatranscriptomes are generated from the RNA of a given sample. The obtained sequencing data will identify active metabolic pathways that are effective in biotechnical processes. For example, the metatranscriptome of Penicillium camemberti and Geotrichum candidum, which are used for the production of Camembert-type cheese, was taken over 77 days of ripening. The functional annotation identified processes during Camembert ripening, such as carbohydrate or protein metabolic processes, which are most active in the first 2 weeks of ripening. Based on these data, attempts can be undertaken to improve cheese quality assessment (Lessard et al. 2014).

\section{Identification of biosynthesis genes and their related metabolic pathways}

An essential aspect for biotechnological applications is knowledge of the genes involved in the biosynthesis of a given product, as well as detection of the metabolic pathways that provide the required precursors. However, when the functional assignment of genes and the related pathways are unknown, it can be achieved by functional genomics approaches. Transcriptomic data of A. oryzae strains inoculated in media with different kojic acid biosynthesis rates were used for comparative analysis, in order to identify genes involved in the biosynthesis of this important organic acid (Terabayashi et al. 2010). Identification of the involved genes allows targeted strain improvement by the overexpression of the related biosynthesis genes. Most biosynthesis pathways contain one or more rate-limiting steps representing interesting adjustment screws for product titers. For example, the biosynthesis of the phytohormone gibberellic acid produced by F. fujikuroi was enhanced by the overexpression of two genes encoding a geranylgeranyl diphosphate synthase 2 and a bifunctional ent-copalyldiphosphate synthase/ent-kaurene synthase. Both are key enzymes of the gibberellic acid pathway (Albermann et al. 2013). For P. chrysogenum, it was shown that even in production strains, the additional overexpression of penDE can lead to elevated penicillin yields (Weber et al. 2012). The acyl-coenzyme A: isopenicillin $N$ acyltransferase encoded by pen $D E$ is involved in the last biosynthetic step of penicillin formation, which is the exchange of the sidechain L- $\alpha$-aminoadipic acid with phenylacetic acid or phenoxyacetic acid. However, the overexpression of penDE needs to be balanced since very high levels of the encoded enzyme lead to accumulation of 6-aminopenicillic acid instead of penicillin. In this case, the formation of 6 aminopenicillic acid by uncontrolled removal of the sidechain of penicillin occurs probably due to an insufficient supply with sidechain precursors. The supply of precursors is also a very promising field for strain improvement. The involved pathways and potential bottlenecks within them can also be identified using omics approaches. In A. nidulans, transcriptome analysis combined with flux and physiology data was used to propose a model describing the competition between biomass formation and polyketide production for the available acetyl coenzyme A (Panagiotou et al. 2009).

\section{Comparison of production and wild-type strains}

The extensive random mutagenesis in strain improvement programs generated production strains that differ substantially from their ancestral wild type at the genomic level. Genome rearrangements were previously demonstrated by pulsed-field gel electrophoresis (Walz and Kück 1991). The current availability of genome sequences from wild-type and production strains of a broad range of industrial filamentous fungi identified genome differences down to nucleotide resolution. Identified changes can be valuable indicators for targeted strain improvement using molecular genetic tools.

Comparison of the genome sequences from the $T$. reesei production strains NG14 and RUT-C30 with the wild-type strain QM6a revealed 223 SNPs, 15 small deletions or insertions, and 18 larger deletions responsible for the loss of more than $100 \mathrm{~kb}$ (Le Crom et al. 2009). More than half of the single nucleotide polymorphisms (SNPs) introduced within coding sequences are non-synonymous and can therefore lead to changes in protein functionality. A few of these changes were analyzed in more detail, for example, truncation of the $g l s 2 \alpha$ gene encoding a $\beta$-glucosidase subunit in the production strain RUT-C30 (Geysens et al. 2005). Furthermore, the truncation of the transcription factor Cre1, caused by a premature stop codon introduced in the encoding gene leads to a loss of carbon catabolite repression (Ilmen et al. 1996). This enables the production of cellulases using glucose as a carbon source, which prevents cellulase production in wild-type strains. These findings are applicable to other industrially relevant fungi. It was, for instance, shown that deletion of the crel gene can be used to increase penicillin titers in $P$. chrysogenum production strains (Cepeda-García et al. 2014). However, not every genomic alteration introduced by classical strain improvement using random mutagenesis can be connected to improved product formation. Production strains of T. reesei have lost a genomic fragment with a size of $85 \mathrm{~kb}$ compromising 29 genes (Seidl et al. 2008). But the loss of these fragments has no effect on cellulase production (Vitikainen et al. 2010). An alternative approach is the comparison of strains that are unable to synthesize a given product. The genome sequence of a cellulase-negative $T$. reesei strain revealed an SNP in the xyrl gene leading to a truncated and biologically inactive transcription factor (Lichius et al. 2015).

In $P$. chrysogenum, comparative genomics was used to analyze strain improvement processes. In a comparison of the genomes of the wild-type strain NRRL1951 with two derived 
production strains, a total of 558 SNPs were identified in coding regions leading to changes in the amino acid sequences of the encoded proteins (Salo et al. 2015). In this comparison, the authors identified SNPs in $29 \%$ of the secondary metabolite cluster. Besides the deactivation of secondary metabolite clusters, no enrichment of functional categories of mutated genes in production strains was observed. This led to the hypothesis that these clusters were inactivated in favor of $\beta$-lactam biosynthesis. An example of such inactivation is the sorbicillinoid biosynthesis cluster, which is involved in the biosynthesis of a yellow-colored pigment produced in wild-type strains. The formation of this class of pigments can hamper the downstream purification of secondary metabolites and therefore was also eliminated in other industrial filamentous fungi such as $A$. chrysogenum and T. reesei (Derntl et al. 2016).

The genetic alterations in production strains in comparison to the wild type were a relevant aspect of strain improvement programs for a long time. So far, SNP analysis has not provided substantial evidence for the preferred mutagenesis of genes from distinct functional categories.

An alternative approach to decipher genetic alterations in production strains was recently successfully conducted. The comparative transcriptional analysis of the wild-type and production strains from the two antibiotic producers $A$. chrysogenum and P. chrysogenum (Terfehr et al. 2017), revealed that both only distantly related industrial fungi show common transcriptional adaptions towards high-level $\beta$-lactam antibiotic biosynthesis. For example, industrial strains from both fungi show an enrichment of differentially regulated genes associated with the supply of precursors and energy for $\beta$-lactam production. Furthermore, genes required for pathways and cellular functions that are not needed for antibiotic production are downregulated. In addition, the effect of Velvet, a major regulator of secondary metabolism in filamentous fungi, was investigated in production strains of $A$. chrysogenum and $P$. chrysogenum. This global regulator controls approximately $50 \%$ of all secondary metabolite clusters. Most importantly, strain improvement and Velvet affect the expression of a large set of genes in a similar manner in both improved industrial fungi. Comparisons of production and wild-type strains can be also conducted at the protein level. Using two-dimensional electrophoresis, it was possible to identify protein level changes between a wild-type strain and two production strains with moderate and high penicillin biosynthesis capacities (Jami et al. 2010). The two production strains have undergone a global metabolic reorganization. They showed an overrepresentation of enzymes involved in penicillin precursor and energy metabolism, while proteins involved in stress response, virulence, and the biosynthesis of other secondary metabolites were nearly lost. A similar comparison with A. chrysogenum strains also identified comparable changes (Liu et al. 2015). Since thiamine biosynthesis enzymes are overrepresented in the production strain, this metabolism seems to be beneficial for cephalosporin $\mathrm{C}$ biosynthesis in this fungus. These conclusions are based on knock-down and overexpression studies and provide the potential to identify targets for strain improvement.

Besides understanding differences in secondary metabolism, proteome studies are used to identify bottlenecks during the secretion of recombinant proteins. The comparison of $A$. nidulans strains, showing different capacities of recombinant protein production, disclosed alterations in proteins related to amino acid metabolism, ribosome biogenesis, translation, and endoplasmic reticulum and provides targets for rational strain improvement (Zubieta et al. 2018). Strains used for the comparisons mentioned above can be derived from long-term strain improvement programs, but also from forward genetic approaches. Using the latter approach together with whole genome sequencing enables the identification of the low-affinity glucose transporter MstC from A. niger, whose deletion improved secretion of heterologous proteins (Reilly et al. 2018).

A different approach was used for Aspergillus species. Here, a genus-wide comparative genomics approach was used to identify genomic differences concerning primary and secondary metabolism, stress response, biomass degradation, and signal transduction (de Vries et al. 2017). In the case of organic acid production, the authors identified a link between the number of isoenzymes and the phylogeny of the analyzed fungi. Members from the section Nigri possess extra isoenzymes relevant for citrate and gluconic acid production, which correlates with the increased capacity of these strains to produce organic acid.

\section{Optimizing endogenous metabolic pathways}

The identification of competing metabolic pathways can be a valuable approach for strain improvement by genetic manipulation. In this context, pathways that stay in direct competition because of using the same substrate and pathways that degrade the desired product are of great interest. In addition to competing pathways, transport-associated processes can also be a bottleneck. Comparisons of strains with different characteristics concerning these problems and basic research can provide hints for optimization.

Because of the high secretion capacity, filamentous fungi are broadly used in industry to produce endogenous and heterologous products, particularly, A. oryzae, A. niger, and $T$. reesei. However, these fungi also secrete a couple of proteases which will degrade the products of interest and thus may diminish the maximum product yield. Therefore, proteasedeficient Trichoderma and Aspergillus strains were generated to circumvent this problem. Using A. oryzae strains that lack two proteases, the heterologous production of human lysozyme and bovine chymosin was further improved by deletion of additional protease-encoding genes. A consequence was the generation of a protease-deficient strain with an enhanced 
capability of heterologous protein production (Yoon et al. 2011). In a similar approach with $T$. reesei strains, the deletion of nine protease-encoding genes led to a doubled interferon alpha-2b production (Landowski et al. 2016). These yields are comparable to those achieved with $E$. coli, where the product must be refolded from inclusion bodies. The $T$. reesei system even outperforms the Pichia pastoris system, which was used frequently for interferon production. Another option to decrease extracellular protease levels is the modification of the underlying gene regulation. The transcription factor PrtT from A. niger is applicable for this approach since it regulates the expression of extracellular protease-encoding genes (Punt et al. 2008). The abovementioned strategies, developed for wellknown production hosts, may be transferred to lessestablished production organisms. Genome sequencing of the thermophilic filamentous fungus Myceliophthora thermophila and subsequent identification of proteaseencoding genes were used to generate protease-deficient strains for cellulase production (Berka et al. 2011; Szabo et al. 2013).

Misfolding is another problem in the production of heterologous proteins. Based on transcriptomic data, it was shown that the biosynthesis of heterologous proteins activates the unfolded protein response (UPR) in A. niger (Guillemette et al. 2007; Kwon et al. 2012). The activation of UPR leads to proteolysis, which can reduce the product yield substantially. Using the transcriptomic data, it was possible to identify core genes involved in this pathway as promising targets for strain improvement. The amount of secreted heterologous proteins was increased by deletion of the doaA gene, encoding an essential factor for ubiquitin-mediated proteolysis. This was further optimized by overexpression of the $s t t C$ gene, encoding a protein involved in the glycosylation of secreted products (Jacobs et al. 2009).

Autophagy is a highly conserved intracellular pathway that degrades non-functional or not needed cellular components. This process may affect high yield expression of proteins and is thus a promising target for strain improvement programs. In chymosin-producing $A$. oryzae strains, the inactivation of autophagy leads to a threefold increase in product formation (Yoon et al. 2013). Besides heterologous protein production, secondary metabolite production can also be affected by autophagy. Autophagy-deficient $P$. chrysogenum strains have an increased amount of penicillin biosynthesis enzymes and thus synthesize more penicillin (Bartoszewska et al. 2011). Similarly, the lack of Atg1, which is essential for autophagosome formation, led to increased cephalosporin $\mathrm{C}$ production rates in A. chrysogenum strains (Wang et al. 2014). However, the modification of autophagy does not necessarily lead to increased product yields. The deletion of Acatg11 results in autophagy deficiency and a reduced cephalosporin $\mathrm{C}$ titer in the corresponding $A$. chrysogenum strain (Liu et al. 2017a).
Protein degradation can also be a problem if the desired heterologous product is usually catabolized by the host organism. In order to produce galactaric acid using A. niger, a gene coding for a uronate dehydrogenase of prokaryotic origin was introduced into the genome. In addition to that, endogenous pathways for galactaric acid degradation were identified using RNA-seq data and inactivated using the CRISPR/Cas9 system (Kuivanen et al. 2016).

\section{Product modification for optimized application}

Products synthesized by filamentous fungi are used in a broad area of applications. This area ranges from proteases and lipases in washing agents in private households to the industrial scale use of enzymes, e.g., cellulases for bioethanol production. Based on the diverse areas of application, the products must meet different criteria for different physical and chemical parameters. While enzymes in washing agents often need ambient temperature optima, the vast majority of industrial used enzymes should be thermotolerant (Struvay and Feller 2012). High temperatures offer advantages, e.g., faster conversation rates, a reduced risk of contamination, and an increased mass transfer (Grigoriev et al. 2011). However, even heat lability can also be beneficial because these enzymes can be easily inactivated by a moderate increase in temperature. Another crucial parameter for the activity and stability of enzymes is the $\mathrm{pH}$ optimum. For instance, acid-stable cellulases are highly required for bioethanol production, because substrates are often treated with acids prior to the enzymatic processes. Functional analysis of genomes and even metagenomes from extremophiles can help to identify enzymes that meet these criteria, even if the original host cannot be used for production.

Phytases, phosphohydrolases that catalyze the hydrolysis of phytic acid, releasing bioavailable phosphorus, were optimized based on various homologous phytase-encoding genes. The construction of a consensus phytase gene led to an enzyme with improved activity and thermostability (Lehmann et al. 2000; Tomschy et al. 2000). In T. reesei, the temperature optimum of endoglucanase was increased by $16{ }^{\circ} \mathrm{C}$ in a similar approach (Trudeau et al. 2014). Besides optimizing enzymes to fit certain criteria, one can also directly choose enzymes from extremophiles. The comparative genomic analysis of the two thermophilic biomass-degrading fungi Myceliophthora thermophila and Thielavia terrestris disclosed a wealth of thermostable enzymes for hydrolysis of all major polysaccharides occurring in biomass (Berka et al. 2011). Via the heterologous expression of a thermostable $\beta$-glucosidase of Neosartorya fischeri, a closely related species to A. fumigatus, the cellulytic activity of T. reesei was improved (Xue et al. 2016). 
Another alternative strategy is the use of metagenome libraries. Using a library derived from deep-sea sediments, a cold-active lipase was identified with an optimal activity at $25{ }^{\circ} \mathrm{C}$ (Zhiwei et al. 2015). Furthermore, a metagenomic fosmid library obtained from the microbial community of a biogas digester provided a new cellulase gene, which was fused with the $c b h 1$ gene from $T$. reesei. Rut-C30 strains expressing this enzyme showed a higher cellulytic activity and concentrations of hydrolytically released glucose increased by about 20\% (Geng et al. 2012). Besides the search for enzymes with higher activity, metagenomics can also be used to identify enzymes with new substrate specificities.

\section{Conclusion}

Over four decades ago, the DNA-mediated transformation systems for filamentous fungi were first described. Since then, many different molecular tools were developed that provide the necessary basis to manipulate filamentous fungi for a broad range of biotechnical applications. However, we are still searching for promoter systems that have strong and tuneable expression properties, not only in a few host systems but rather in a broad range of biotechnically used fungi. Another central question concerns the functionality of heterologous proteins. For example, the post-translational protein modification is the main problem when human protein genes are functionally expressed in diverse fungal hosts. We still await tightly regulated expression systems that allow the controlled glycosylation of mammalian proteins. We foresee that the growing information obtained from functional genomics regulatory annotation data combined with transcriptional expression assays can identify complex regulatory networks that allow the synthesis of secondary metabolites, which still remain to be discovered.

Acknowledgements We thank Frau Gabriele Frenßen-Schenkel for the art work and our colleagues for discussion, and we apologize for not referring published work from our colleagues, which might be relevant for this review.

\section{Compliance with ethical standards}

Conflict of interest The authors declare that they have no conflict of interest.

Ethical approval This article does not contain any studies with human participants or animals performed by any of the authors.

Open Access This article is distributed under the terms of the Creative Commons Attribution 4.0 International License (http:// creativecommons.org/licenses/by/4.0/), which permits unrestricted use, distribution, and reproduction in any medium, provided you give appropriate credit to the original author(s) and the source, provide a link to the Creative Commons license, and indicate if changes were made.

\section{References}

Albermann S, Linnemannstons P, Tudzynski B (2013) Strategies for strain improvement in Fusarium fujikuroi: overexpression and localization of key enzymes of the isoprenoid pathway and their impact on gibberellin biosynthesis. Appl Microbiol Biotechnol 97(7): 2979-2995. https://doi.org/10.1007/s00253-012-4377-5

Alberti F, Foster GD, Bailey AM (2017) Natural products from filamentous fungi and production by heterologous expression. Appl Microbiol Biotechnol 101(2):493-500. https://doi.org/10.1007/ s00253-016-8034-2

Antunes MS, Hodges TK, Carpita NC (2016) A benzoate-activated promoter from Aspergillus niger and regulation of its activity. Appl Microbiol Biotechnol 100(12):5479-5489. https://doi.org/10.1007/ s00253-016-7373-3

Archer DB (2000) Filamentous fungi as microbial cell factories for food use. Curr Opin Biotechnol 11(5):478-483

Bartoszewska M, Kiel JA, Bovenberg RA, Veenhuis M, van der Klei IJ (2011) Autophagy deficiency promotes beta-lactam production in Penicillium chrysogenum. Appl Environ Microbiol 77(4):14131422. https://doi.org/10.1128/AEM.01531-10

Becker J, Lange A, Fabarius J, Wittmann C (2015) Top value platform chemicals: bio-based production of organic acids. Curr Opin Biotechnol 36:168-175. https://doi.org/10.1016/j.copbio.2015.08. 022

Berka RM, Grigoriev IV, Otillar R, Salamov A, Grimwood J, Reid I, Ishmael N, John T, Darmond C, Moisan MC, Henrissat B, Coutinho PM, Lombard V, Natvig DO, Lindquist E, Schmutz J, Lucas S, Harris P, Powlowski J, Bellemare A, Taylor D, Butler G, de Vries RP, Allijn IE, van den Brink J, Ushinsky S, Storms R, Powell AJ, Paulsen IT, Elbourne LD, Baker SE, Magnuson J, Laboissiere S, Clutterbuck AJ, Martinez D, Wogulis M, de Leon AL, Rey MW, Tsang A (2011) Comparative genomic analysis of the thermophilic biomass-degrading fungi Myceliophthora thermophila and Thielavia terrestris. Nat Biotechnol 29(10):922927. https://doi.org/10.1038/nbt.1976

Blatzer M, Gsaller F, Abt B, Schrettl M, Specht T, Haas H (2014) An endogenous promoter for conditional gene expression in Acremonium chrysogenum: the xylan and xylose inducible promoter xyl1P. J Biotechnol 169:82-86. https://doi.org/10.1016/j.jbiotec. 2013.11.003

Bloemendal S, Löper D, Terfehr D, Kopke K, Kluge J, Teichert I, Kück U (2014) Tools for advanced and targeted genetic manipulation of the beta-lactam antibiotic producer Acremonium chrysogenum. J Biotechnol 169:51-62. https://doi.org/10.1016/j.jbiotec.2013.10. 036

Bockamp E, Maringer M, Spangenberg C, Fees S, Fraser S, Eshkind L, Oesch F, Zabel B (2002) Of mice and models: improved animal models for biomedical research. Physiol Genomics 11(3):115-132. https://doi.org/10.1152/physiolgenomics.00067.2002

Boel E, Hansen MT, Hjort I, Høegh I, Fiil NP (1984) Two different types of intervening sequences in the glucoamylase gene from Aspergillus niger. EMBO J 3(7):1581-1585

Bok JW, Ye R, Clevenger KD, Mead D, Wagner M, Krerowicz A, Albright JC, Goering AW, Thomas PM, Kelleher NL, Keller NP, Wu CC (2015) Fungal artificial chromosomes for mining of the fungal secondary metabolome. BMC Genomics 16:343. https:// doi.org/10.1186/s12864-015-1561-x

Bulakhov AG, Volkov PV, Rozhkova AM, Gusakov AV, Nemashkalov VA, Satrutdinov AD, Sinitsyn AP (2017) Using an inducible promoter of a gene encoding Penicillium verruculosum glucoamylase for production of enzyme preparations with enhanced cellulase performance. PLoS One 12(1):e0170404. https://doi.org/10.1371/ journal.pone. 0170404 
Case ME, Schweizer M, Kushner SR, Giles NH (1979) Efficient transformation of Neurospora crassa by utilizing hybrid plasmid DNA. Proc Natl Acad Sci U S A 76(10):5259-5263

Cepeda-García C, Domínguez-Santos R, García-Rico RO, GarcíaEstrada C, Cajiao A, Fierro F, Martín JF (2014) Direct involvement of the CreA transcription factor in penicillin biosynthesis and expression of the $p c b A B$ gene in Penicillium chrysogenum. Appl Microbiol Biotechnol 98(16):7113-7124. https://doi.org/10.1007/ s00253-014-5760-1

de Vries RP, Riley R, Wiebenga A, Aguilar-Osorio G, Amillis S, Uchima CA, Anderluh G, Asadollahi M, Askin M, Barry K, Battaglia E, Bayram Ö, Benocci T, Braus-Stromeyer SA, Caldana C, Cánovas D, Cerqueira GC, Chen F, Chen W, Choi C, Clum A, Dos Santos RA, Damásio AR, Diallinas G, Emri T, Fekete E, Flipphi M, Freyberg S, Gallo A, Gournas C, Habgood R, Hainaut M, Harispe ML, Henrissat B, Hildén KS, Hope R, Hossain A, Karabika E, Karaffa L, Karanyi Z, Kraševec N, Kuo A, Kusch H, LaButti K, Lagendijk EL, Lapidus A, Levasseur A, Lindquist E, Lipzen A, Logrieco AF, MacCabe A, Mäkelä MR, Malavazi I, Melin P, Meyer V, Mielnichuk N, Miskei M, Molnár ÁP, Mulé G, Ngan CY, Orejas M, Orosz E, Ouedraogo JP, Overkamp KM, Park HS, Perrone G, Piumi F, Punt PJ, Ram AF, Ramón A, Rauscher S, Record E, Riano-Pachon DM, Robert V, Rohrig J, Ruller R, Salamov A, Salih NS, Samson RA, Sándor E, Sanguinetti M, Schütze T, Sepčić K, Shelest E, Sherlock G, Sophianopoulou V, Squina FM, Sun H, Susca A, Todd RB, Tsang A, Unkles SE, van de Wiele N, van Rossen-Uffink D, Oliveira JV, Vesth TC, Visser J, Yu JH, Zhou M, Andersen MR, Archer DB, Baker SE, Benoit I, Brakhage AA, Braus GH, Fischer R, Frisvad JC, Goldman GH, Houbraken J, Oakley B, Pócsi I, Scazzocchio C, Seiboth B, vanKuyk PA, Wortman J, Dyer PS, Grigoriev IV (2017) Comparative genomics reveals high biological diversity and specific adaptations in the industrially and medically important fungal genus Aspergillus. Genome Biol 18(1):28. https://doi.org/10.1186/s13059017-1151-0

Demain AL (2007) The business of biotechnology. Ind Biotechnol 3: 269-283. https://doi.org/10.1089/ind.2007.3.269

Demain AL, Vaishnav P (2009) Production of recombinant proteins by microbes and higher organisms. Biotechnol Adv 27(3):297-306. https://doi.org/10.1016/j.biotechadv.2009.01.008

Derntl C, Rassinger A, Srebotnik E, Mach RL, Mach-Aigner AR (2016) Identification of the main regulator responsible for synthesis of the typical yellow pigment produced by Trichoderma reesei. Appl Environ Microbiol 82(20):6247-6257. https://doi.org/10.1128/ AEM.01408-16

Dufosse L, Fouillaud M, Caro Y, Mapari SA, Sutthiwong N (2014) Filamentous fungi are large-scale producers of pigments and colorants for the food industry. Curr Opin Biotechnol 26:56-61. https:// doi.org/10.1016/j.copbio.2013.09.007

Eberle J, Russo VE (1994) Neurospora crassa blue light-inducible gene bli-3. Biochem Mol Biol Int 34(4):737-744

Finn RD, Coggill P, Eberhardt RY, Eddy SR, Mistry J, Mitchell AL, Potter SC, Punta M, Qureshi M, Sangrador-Vegas A, Salazar GA, Tate J, Bateman A (2016) The Pfam protein families database: towards a more sustainable future. Nucleic Acids Res 44(D1):D279D285. https://doi.org/10.1093/nar/gkv1344

Fischer S, Engstler C, Procopio S, Becker T (2016) Induced gene expression in industrial Saccharomyces pastorianus var. carlsbergensis TUM 34/70: evaluation of temperature and ethanol inducible native promoters. FEMS Yeast Res 16(3):fow014. https://doi.org/10.1093/ femsyr/fow014

Galperin MY, Makarova KS, Wolf YI, Koonin EV (2015) Expanded microbial genome coverage and improved protein family annotation in the COG database. Nucleic Acids Res 43(Database issue):D261D269. https://doi.org/10.1093/nar/gku1223
Ganeva V, Galutzov B, Angelova B, Suckow M (2017) Electroinduced extraction of human ferritin heavy chain expressed in Hansenula polymorpha. Appl Biochem Biotechnol 184:1286-1307. https:// doi.org/10.1007/s12010-017-2627-9

Geib E, Brock M (2017) ATNT: an enhanced system for expression of polycistronic secondary metabolite gene clusters in Aspergillus niger. Fungal Biol Biotechnol 4:13. https://doi.org/10.1186/ s40694-017-0042-1

Geng A, Zou G, Yan X, Wang Q, Zhang J, Liu F, Zhu B, Zhou Z (2012) Expression and characterization of a novel metagenome-derived cellulase Exo2b and its application to improve cellulase activity in Trichoderma reesei. Appl Microbiol Biotechnol 96(4):951-962. https://doi.org/10.1007/s00253-012-3873-y

Geysens S, Pakula T, Uusitalo J, Dewerte I, Penttila M, Contreras R (2005) Cloning and characterization of the glucosidase II alpha subunit gene of Trichoderma reesei: a frameshift mutation results in the aberrant glycosylation profile of the hypercellulolytic strain RutC30. Appl Environ Microbiol 71(6):2910-2924. https://doi.org/10. 1128/AEM.71.6.2910-2924.2005

Giles NH, Case ME, Baum J, Geever R, Huiet L, Patel V, Tyler B (1985) Gene organization and regulation in the $q a$ (quinic acid) gene cluster of Neurospora crassa. Microbiol Rev 49(3):338-358

Gossen M, Bujard H (1992) Tight control of gene expression in mammalian cells by tetracycline-responsive promoters. Proc Natl Acad Sci U S A 89(12):5547-5551

Gouka RJ, Hessing JG, Punt PJ, Stam H, Musters W, Van den Hondel CA (1996) An expression system based on the promoter region of the Aspergillus awamori 1,4-beta-endoxylanase A gene. Appl Microbiol Biotechnol 46(1):28-35

Grigoriev IV, Cullen D, Goodwin SB, Hibbett D, Jeffries TW, Kubicek CP, Kuske C, Magnuson JK, Martin F, Spatafora JW, Tsang A, Baker SE (2011) Fueling the future with fungal genomics. Mycology 2(3):192-209. https://doi.org/10.1080/21501203.2011. 584577

Gsaller F, Blatzer M, Abt B, Schrettl M, Lindner H, Haas H (2013) The first promoter for conditional gene expression in Acremonium chrysogenum: iron starvation-inducible mir1(P). J Biotechnol 163(1):77-80. https://doi.org/10.1016/j.jbiotec.2012.10.008

Guillemette T, van Peij N, Goosen T, Lanthaler K, Robson GD, van den Hondel CA, Stam H, Archer DB (2007) Genomic analysis of the secretion stress response in the enzyme-producing cell factory Aspergillus niger. BMC Genomics 8:158. https://doi.org/10.1186/ 1471-2164-8-158

Haft DH, Selengut JD, White O (2003) The TIGRFAMs database of protein families. Nucleic Acids Res 31(1):371-373

Havlik D, Brandt U, Bohle K, Fleissner A (2017) Establishment of Neurospora crassa as a host for heterologous protein production using a human antibody fragment as a model product. Microb Cell Factories 16(1):128. https://doi.org/10.1186/s12934-017-0734-5

$\mathrm{Hu}$ Y, Zhu B (2016) Study on genetic engineering of Acremonium chrysogenum, the cephalosporin C producer. Synth Syst Biotechnol 1(3):143-149. https://doi.org/10.1016/j.synbio.2016.09. 002

Hurley JM, Chen CH, Loros JJ, Dunlap JC (2012) Light-inducible system for tunable protein expression in Neurospora crassa. G3 2(10): 1207-1212. https://doi.org/10.1534/g3.112.003939

Ilmen M, Thrane C, Penttila M (1996) The glucose repressor gene crel of Trichoderma: isolation and expression of a full-length and a truncated mutant form. Mol Gen Genet 251(4):451-460

Jacobs DI, Olsthoorn MM, Maillet I, Akeroyd M, Breestraat S, Donkers S, van der Hoeven RA, van den Hondel CA, Kooistra R, Lapointe T, Menke H, Meulenberg R, Misset M, Müller WH, van Peij NN, Ram A, Rodriguez S, Roelofs MS, Roubos JA, van Tilborg MW, Verkleij AJ, Pel HJ, Stam H, Sagt CM (2009) Effective lead selection for improved protein production in Aspergillus niger based on 
integrated genomics. Fungal Genet Biol 46(Suppl 1):S141-S152. https://doi.org/10.1016/j.fgb.2008.08.012

Jami MS, Barreiro C, Garcia-Estrada C, Martin JF (2010) Proteome analysis of the penicillin producer Penicillium chrysogenum: characterization of protein changes during the industrial strain improvement. Mol Cell Proteomics 9(6):1182-1198. https://doi.org/10.1074/mcp. M900327-MCP200

Janevska S, Arndt B, Baumann L, Apken LH, Mauriz Marques LM, Humpf HU, Tudzynski B (2017) Establishment of the inducible Tet-On System for the activation of the silent trichosetin gene cluster in Fusarium fujikuroi. Toxins 9(4) https://doi.org/10.3390/ toxins 9040126

Janus D, Hortschansky P, Kück U (2008) Identification of a minimal crel promoter sequence promoting glucose-dependent gene expression in the beta-lactam producer Acremonium chrysogenum. Curr Genet 53(1):35-48. https://doi.org/10.1007/s00294-007-0164-8

Kiesenhofer DP, Mach RL, Mach-Aigner AR (2018) Influence of cis element arrangement on promoter strength in Trichoderma reesei. Appl Environ Microbiol 84(1):e01742-e01717. https://doi.org/10. 1128/AEM.01742-17

Kim S-I, Ha B-S, Kim M-S, Park M, Ro H-S (2016) Evaluation of copper-inducible fungal laccase promoter in foreign gene expression in Pichia pastoris. Biotechnol Bioprocess Eng 21(1):53-59. https:// doi.org/10.1007/s12257-015-0567-1

Kopke K, Hoff B, Kück U (2010) Application of the Saccharomyces cerevisiae $\mathrm{FLP} / F R T$ recombination system in filamentous fungi for marker recycling and construction of knockout strains devoid of heterologous genes. Appl Environ Microbiol 76(14):4664-4674

Krappmann S (2017) CRISPR-Cas9, the new kid on the block of fungal molecular biology. Med Mycol 55(1):16-23. https://doi.org/10. 1093/mmy/myw097

Kück U, Hoff B (2010) New tools for the genetic manipulation of filamentous fungi. Appl Microbiol Biotechnol 86(1):51-62. https://doi. org/10.1007/s00253-009-2416-7

Kuivanen J, Penttila M, Richard P (2015) Metabolic engineering of the fungal D-galacturonate pathway for L-ascorbic acid production. Microb Cell Factories 14:2. https://doi.org/10.1186/s12934-0140184-2

Kuivanen J, Wang YJ, Richard P (2016) Engineering Aspergillus niger for galactaric acid production: elimination of galactaric acid catabolism by using RNA sequencing and CRISPR/Cas9. Microb Cell Factories 15(1):210. https://doi.org/10.1186/s12934-016-0613-5

Künkel W, Berger D, Risch S, Wittmann-Bresinsky B (1992) Genetic instability of industrial strains of Penicillium chrysogenum. Appl Microbiol Biotechnol 36(4):499-502

Kwon MJ, Jørgensen TR, Nitsche BM, Arentshorst M, Park J, Ram AF, Meyer V (2012) The transcriptomic fingerprint of glucoamylase over-expression in Aspergillus niger. BMC Genomics 13:701. https://doi.org/10.1186/1471-2164-13-701

Lamb TM, Vickery J, Bell-Pedersen D (2013) Regulation of gene expression in Neurospora crassa with a copper responsive promoter. G3 3(12):2273-2280. https://doi.org/10.1534/g3.113.008821

Landowski CP, Mustalahti E, Wahl R, Croute L, Sivasiddarthan D, Westerholm-Parvinen A, Sommer B, Ostermeier C, Helk B, Saarinen J, Saloheimo M (2016) Enabling low cost biopharmaceuticals: high level interferon alpha-2b production in Trichoderma reesei. Microb Cell Factories 15(1):104. https://doi. org/10.1186/s12934-016-0508-5

Le Crom S, Schackwitz W, Pennacchio L, Magnuson JK, Culley DE, Collett JR, Martin J, Druzhinina IS, Mathis H, Monot F, Seiboth B, Cherry B, Rey M, Berka R, Kubicek CP, Baker SE, Margeot A (2009) Tracking the roots of cellulase hyperproduction by the fungus Trichoderma reesei using massively parallel DNA sequencing. Proc Natl Acad Sci U S A 106(38):16151-16156. https://doi.org/10. 1073/pnas.0905848106
Lee J, Son H, Lee S, Park AR, Lee YW (2010) Development of a conditional gene expression system using a zearalenone-inducible promoter for the ascomycete fungus Gibberella zeae. Appl Environ Microbiol 76(10):3089-3096. https://doi.org/10.1128/AEM.02999-09

Lehmann M, Kostrewa D, Wyss M, Brugger R, D'Arcy A, Pasamontes L, van Loon AP (2000) From DNA sequence to improved functionality: using protein sequence comparisons to rapidly design a thermostable consensus phytase. Protein Eng 13(1):49-57

Lein J (1986) The Panlabs Penicillium strain improvement program. In: Vanek Z, Hostálek Z (eds) Overproduction of microbial metabolites. Butterworths, Stoneham, MA, pp 105-140

Lessard MH, Viel C, Boyle B, St-Gelais D, Labrie S (2014) Metatranscriptome analysis of fungal strains Penicillium camemberti and Geotrichum candidum reveal cheese matrix breakdown and potential development of sensory properties of ripened Camembert-type cheese. BMC Genomics 15:235. https://doi.org/ 10.1186/1471-2164-15-235

Levine M, Cattoglio C, Tjian R (2014) Looping back to leap forward: transcription enters a new era. Cell 157(1):13-25. https://doi.org/10. 1016/j.cell.2014.02.009

Lichius A, Bidard F, Buchholz F, Le Crom S, Martin J, Schackwitz W, Austerlitz T, Grigoriev IV, Baker SE, Margeot A, Seiboth B, Kubicek CP (2015) Genome sequencing of the Trichoderma reesei QM9136 mutant identifies a truncation of the transcriptional regulator XYR1 as the cause for its cellulase-negative phenotype. BMC Genomics 16:326. https://doi.org/10.1186/s12864-015-1526-0

Liu J, Hao T, Hu P, Pan Y, Jiang X, Liu G (2017a) Functional analysis of the selective autophagy related gene Acatg11 in Acremonium chrysogenum. Fungal Genet Biol 107:67-76. https://doi.org/10. 1016/j.fgb.2017.08.006

Liu J, Li J, Shin HD, Du G, Chen J, Liu L (2017b) Metabolic engineering of Aspergillus oryzae for efficient production of 1-malate directly from corn starch. J Biotechnol 262:40-46. https://doi.org/10.1016/ j.jbiotec.2017.09.021

Liu Y, Zhang W, Xie L, Liu H, Gong G, Zhu B, Hu Y (2015) Acthi, a thiazole biosynthesis enzyme, is essential for thiamine biosynthesis and CPC production in Acremonium chrysogenum. Microb Cell Factories 14:50. https://doi.org/10.1186/s12934-015-0235-3

Long L, Zhao H, Ding D, Xu M, Ding S (2018) Heterologous expression of two Aspergillus niger feruloyl esterases in Trichoderma reesei for the production of ferulic acid from wheat bran. Bioprocess Biosyst Eng 41:593-601. https://doi.org/10.1007/s00449-018-1894-3

Mach RL, Strauss J, Zeilinger S, Schindler M, Kubicek CP (1996) Carbon catabolite repression of xylanase I (xyn 1) gene expression in Trichoderma reesei. Mol Microbiol 21(6):1273-1281

Macheleidt J, Scherlach K, Neuwirth T, Schmidt-Heck W, Strassburger M, Spraker J, Baccile JA, Schroeder FC, Keller NP, Hertweck C, Heinekamp T, Brakhage AA (2015) Transcriptome analysis of cyclic AMP-dependent protein kinase A-regulated genes reveals the production of the novel natural compound fumipyrrole by Aspergillus fumigatus. Mol Microbiol 96(1):148-162. https://doi. org/10.1111/mmi.12926

Magana-Ortiz D, Fernandez F, Loske AM, Gomez-Lim MA (2018) Extracellular expression in Aspergillus niger of an antibody fused to Leishmania sp. antigens. Curr Microbiol 75(1):40-48. https://doi. org/10.1007/s00284-017-1348-1

Mallu MR, Vemula S, Ronda SR (2016) Production, purification and characterization of recombinant human antithrombin III by Saccharomyces cerevisiae. Electron J Biotechnol 22:81-89. https://doi.org/10.1016/j.ejbt.2016.06.002

Matsuzawa T, Tohda H, Takegawa K (2013) Ethanol-inducible gene expression using gldl $1+$ ) promoter in the fission yeast Schizosaccharomyces pombe. Appl Microbiol Biotechnol 97(15): 6835-6843. https://doi.org/10.1007/s00253-013-4812-2

Meyer V, Wanka F, van Gent J, Arentshorst M, van den Hondel CA, Ram AF (2011) Fungal gene expression on demand: an inducible, 
tunable, and metabolism-independent expression system for Aspergillus niger. Appl Environ Microbiol 77(9):2975-2983. https://doi.org/10.1128/AEM.02740-10

Mirabito PM, Adams TH, Timberlake WE (1989) Interactions of three sequentially expressed genes control temporal and spatial specificity in Aspergillus development. Cell 57(5):859-868

Müller C, Hjort CM, Hansen K, Nielsen J (2002) Altering the expression of two chitin synthase genes differentially affects the growth and morphology of Aspergillus oryzae. Microbiology 148(Pt 12): 4025-4033. https://doi.org/10.1099/00221287-148-12-4025

Nevalainen KM, Te'o VS, Bergquist PL (2005) Heterologous protein expression in filamentous fungi. Trends Biotechnol 23(9):468474. https://doi.org/10.1016/j.tibtech.2005.06.002

Nielsen JC, Grijseels S, Prigent S, Ji B, Dainat J, Nielsen KF, Frisvad JC, Workman M, Nielsen J (2017) Global analysis of biosynthetic gene clusters reveals vast potential of secondary metabolite production in Penicillium species. Nat Microbiol 2:17044. https://doi.org/10. 1038/nmicrobiol.2017.44

Nyyssönen E, Keränen S (1995) Multiple roles of the cellulase CBHI in enhancing production of fusion antibodies by the filamentous fungus Trichoderma reesei. Curr Genet 28(1):71-79. https://doi.org/10. 1007/bf00311884

Panagiotou G, Andersen MR, Grotkjaer T, Regueira TB, Nielsen J, Olsson L (2009) Studies of the production of fungal polyketides in Aspergillus nidulans by using systems biology tools. Appl Environ Microbiol 75(7):2212-2220. https://doi.org/10.1128/AEM.01461-08

Peng Y, Zhang H, Xu M, Tan MW (2018) A Tet-Off gene expression system for validation of antifungal drug targets in a murine invasive pulmonary aspergillosis model. Sci Rep 8(1):443. https://doi.org/10. 1038/s41598-017-18868-9

Peterson R, Nevalainen H (2012) Trichoderma reesei RUT-C30 - thirty years of strain improvement. Microbiology 158(Pt 1):58-68. https:// doi.org/10.1099/mic.0.054031-0

Punt PJ, Schuren FH, Lehmbeck J, Christensen T, Hjort C, van den Hondel CA (2008) Characterization of the Aspergillus niger prtT, a unique regulator of extracellular protease encoding genes. Fungal Genet Biol 45(12):1591-1599. https://doi.org/10.1016/j.fgb.2008. 09.007

Reilly MC, Kim J, Lynn J, Simmons BA, Gladden JM, Magnuson JK, Baker SE (2018) Forward genetics screen coupled with wholegenome resequencing identifies novel gene targets for improving heterologous enzyme production in Aspergillus niger. Appl Microbiol Biotechnol 102(4):1797-1807. https://doi.org/10.1007/ s00253-017-8717-3

Sainsbury S, Bernecky C, Cramer P (2015) Structural basis of transcription initiation by RNA polymerase II. Nat Rev Mol Cell Biol 16(3): 129-143. https://doi.org/10.1038/nrm3952

Salo OV, Ries M, Medema MH, Lankhorst PP, Vreeken RJ, Bovenberg RA, Driessen AJ (2015) Genomic mutational analysis of the impact of the classical strain improvement program on beta-lactam producing Penicillium chrysogenum. BMC Genomics 16:937. https://doi. org/10.1186/s12864-015-2154-4

Schmidt-Dannert C (2015) NextGen microbial natural products discovery. Microb Biotechnol 8(1):26-28. https://doi.org/10.1111/17517915.12184

Schmidt F-R (2006) From gene to product: the advantage of integrative biotechnology Handbook of pharmaceutical biotechnology. John Wiley \& Sons, Inc., pp 1-52

Schwartze VU, Winter S, Shelest E, Marcet-Houben M, Horn F, Wehner S, Linde J, Valiante V, Sammeth M, Riege K, Nowrousian M, Kaerger K, Jacobsen ID, Marz M, Brakhage AA, Gabaldón T, Bocker S, Voigt K (2014) Gene expansion shapes genome architecture in the human pathogen Lichtheimia corymbifera: an evolutionary genomics analysis in the ancient terrestrial mucorales (Mucoromycotina). PLoS Genet 10(8):e1004496. https://doi.org/ 10.1371/journal.pgen.1004496
Seidl V, Gamauf C, Druzhinina IS, Seiboth B, Hartl L, Kubicek CP (2008) The Hypocrea jecorina (Trichoderma reesei) hypercellulolytic mutant RUT C30 lacks a $85 \mathrm{~kb}$ (29 geneencoding) region of the wild-type genome. BMC Genomics 9:327. https://doi.org/10.1186/1471-2164-9-327

Sharma R, Katoch M, Govindappa N, Srivastava PS, Sastry KN, Qazi GN (2012) Evaluation of the catalase promoter for expressing the alkaline xylanase gene (alx) in Aspergillus niger. FEMS Microbiol Lett 327(1):33-40. https://doi.org/10.1111/j.1574-6968.2011. 02454.x

Sharma R, Katoch M, Srivastava PS, Qazi GN (2009) Approaches for refining heterologous protein production in filamentous fungi. World J Microb Biot 25(12):2083-2094. https://doi.org/10.1007/ s11274-009-0128-X

Shi TQ, Liu GN, Ji RY, Shi K, Song P, Ren LJ, Huang H, Ji XJ (2017) CRISPR/Cas9-based genome editing of the filamentous fungi: the state of the art. Appl Microbiol Biotechnol 101(20):7435-7443. https://doi.org/10.1007/s00253-017-8497-9

Shibui T, Bando K, Misawa S (2013) High-level secretory expression, purification, and characterization of an anti-human Her II monoclonal antibody, trastuzumab, in the methylotrophic yeast Pichia pastoris. Adv Biosci Biotechnol 4(5):7-646. https://doi.org/10. 4236/abb.2013.45084

Shoji J-Y, Maruyama J-I, Arioka M, Kitamoto K (2005) Development of Aspergillus oryzae thiA promoter as a tool for molecular biological studies. FEMS Microbiol Lett 244(1):41-46. https://doi.org/10. 1016/j.femsle.2005.01.014

Siedenberg D, Mestric S, Ganzlin M, Schmidt M, Punt PJ, van den Hondel C, Rinas U (1999) GlaA promoter controlled production of a mutant green fluorescent protein (S65T) by recombinant Aspergillus niger during growth on defined medium in batch and fed-batch cultures. Biotechnol Prog 15(1):43-50. https://doi.org/10. $1021 / \mathrm{bp} 980105 \mathrm{u}$

Soutourina J (2017) Transcription regulation by the mediator complex. Nat Rev Mol Cell Biol 19:262-274. https://doi.org/10.1038/nrm. 2017.115

Spitz F, Furlong EE (2012) Transcription factors: from enhancer binding to developmental control. Nat Rev Genet 13(9):613-626. https:// doi.org/10.1038/nrg3207

Stahl U, Tudzynski P, Kück U, Esser K (1982) Replication and expression of a bacterial-mitochondrial hybrid plasmid in the fungus Podospora anserina. Proc Natl Acad Sci U S A 79(11):3641-3645

Struhl K (1987) Promoters, activator proteins, and the mechanism of transcriptional initiation in yeast. Cell 49(3):295-297

Struvay C, Feller G (2012) Optimization to low temperature activity in psychrophilic enzymes. Int J Mol Sci 13(9):11643-11665. https:// doi.org/10.3390/ijms 130911643

Su X, Schmitz G, Zhang M, Mackie RI, Cann IK (2012) Heterologous gene expression in filamentous fungi. Adv Appl Microbiol 81:1-61. https://doi.org/10.1016/B978-0-12-394382-8.00001-0

Sun A, Peterson R, Te'o J, Nevalainen H (2016) Expression of the mammalian peptide hormone obestatin in Trichoderma reesei. New Biotechnol 33(1):99-106. https://doi.org/10.1016/j.nbt.2015.08.004

Szabo L, Molnar Z, Nemeth AL (2013) Fungal proteases. WO/2013/ 048661,

Tada S, Gomi K, Kitamoto K, Takahashi K, Tamura G, Hara S (1991) Construction of a fusion gene comprising the Taka-amylase A promoter and the Escherichia coli beta-glucuronidase gene and analysis of its expression in Aspergillus oryzae. Mol Gen Genet 229(2):301-306

Terabayashi Y, Sano M, Yamane N, Marui J, Tamano K, Sagara J, Dohmoto M, Oda K, Ohshima E, Tachibana K, Higa Y, Ohashi S, Koike H, Machida M (2010) Identification and characterization of genes responsible for biosynthesis of kojic acid, an industrially important compound from Aspergillus oryzae. Fungal Genet Biol 47(12):953-961. https://doi.org/10.1016/j.fgb.2010.08.014 
Terfehr D, Dahlmann TA, Kück U (2017) Transcriptome analysis of the two unrelated fungal beta-lactam producers Acremonium chrysogenum and Penicillium chrysogenum: Velvet-regulated genes are major targets during conventional strain improvement programs. BMC Genomics 18(1):272. https://doi.org/10.1186/s12864-0173663-0

Thakker C, Martinez I, Li W, San KY, Bennett GN (2015) Metabolic engineering of carbon and redox flow in the production of small organic acids. J Ind Microbiol Biotechnol 42(3):403-422. https:// doi.org/10.1007/s10295-014-1560-y

Tomschy A, Tessier M, Wyss M, Brugger R, Broger C, Schnoebelen L, van Loon AP, Pasamontes L (2000) Optimization of the catalytic properties of Aspergillus fumigatus phytase based on the threedimensional structure. Protein Sci 9(7):1304-1311. https://doi.org/ 10.1110/ps.9.7.1304

Trudeau DL, Lee TM, Arnold FH (2014) Engineered thermostable fungal cellulases exhibit efficient synergistic cellulose hydrolysis at elevated temperatures. Biotechnol Bioeng 111(12):2390-2397. https:// doi.org/10.1002/bit.25308

Tsuchiya K, Tada S, Gomi K, Kitamoto K, Kumagai C, Tamura G (1992) Deletion analysis of the Taka-amylase A gene promoter using a homologous transformation system in Aspergillus oryzae. Biosci Biotechnol Biochem 56(11):1849-1853. https://doi.org/10.1271/ bbb.56.1849

Vitikainen M, Arvas M, Pakula T, Oja M, Penttilä M, Saloheimo M (2010) Array comparative genomic hybridization analysis of Trichoderma reesei strains with enhanced cellulase production properties. BMC Genomics 11:441. https://doi.org/10.1186/1471-2164$11-441$

Vogt K, Bhabhra R, Rhodes JC, Askew DS (2005) Doxycyclineregulated gene expression in the opportunistic fungal pathogen Aspergillus fumigatus. BMC Microbiol 5:1. https://doi.org/10. 1186/1471-2180-5-1

Walz M, Kück U (1991) Polymorphic karyotypes in related Acremonium strains. Curr Genet 19(2):73-76

Wang H, Pan Y, Hu P, Zhu Y, Li J, Jiang X, Liu G (2014) The autophagyrelated gene Acatgl is involved in conidiation and cephalosporin production in Acremonium chrysogenum. Fungal Genet Biol 69: 65-74. https://doi.org/10.1016/j.fgb.2014.06.004

Wanka F, Cairns T, Boecker S, Berens C, Happel A, Zheng X, Sun J, Krappmann S, Meyer V (2016) Tet-on, or Tet-off, that is the question: advanced conditional gene expression in Aspergillus. Fungal Genet Biol 89:72-83. https://doi.org/10.1016/j.fgb.2015.11.003

Ward OP (2012) Production of recombinant proteins by filamentous fungi. Biotechnol Adv 30(5):1119-1139. https://doi.org/10.1016/j. biotechadv.2011.09.012
Waring RB, May GS, Morris NR (1989) Characterization of an inducible expression system in Aspergillus nidulans using alcA and tubulincoding genes. Gene 79(1):119-130

Weber SS, Polli F, Boer R, Bovenberg RA, Driessen AJ (2012) Increased penicillin production in Penicillium chrysogenum production strains via balanced overexpression of isopenicillin $\mathrm{N}$ acyltransferase. Appl Environ Microbiol 78(19):7107-7113. https://doi.org/10.1128/ AEM.01529-12

Woo YH, Li WH (2011) Gene clustering pattern, promoter architecture, and gene expression stability in eukaryotic genomes. Proc Natl Acad Sci U S A 108(8):3306-3311. https://doi.org/10.1073/pnas. 1100210108

Xue X, Wu Y, Qin X, Ma R, Luo H, Su X, Yao B (2016) Revisiting overexpression of a heterologous $\beta$-glucosidase in Trichoderma reesei: fusion expression of the Neosartorya fischeri $B g l 3 A$ to $c b h 1$ enhances the overall as well as individual cellulase activities. Microb Cell Factories 15(1):122. https://doi.org/10.1186/s12934-016-0520-9

Yin X, Shin HD, Li J, Du G, Liu L, Chen J (2017) Pgas, a low-pHinduced promoter, as a tool for dynamic control of gene expression for metabolic engineering of Aspergillus niger. Appl Environ Microbiol 83(6):e03222-e03216. https://doi.org/10.1128/AEM. 03222-16

Yoon J, Kikuma T, Maruyama J, Kitamoto K (2013) Enhanced production of bovine chymosin by autophagy deficiency in the filamentous fungus Aspergillus oryzae. PLoS One 8(4):e62512. https://doi.org/ 10.1371/journal.pone.0062512

Yoon J, Maruyama J, Kitamoto K (2011) Disruption of ten protease genes in the filamentous fungus Aspergillus oryzae highly improves production of heterologous proteins. Appl Microbiol Biotechnol 89(3): 747-759. https://doi.org/10.1007/s00253-010-2937-0

Zadra I, Abt B, Parson W, Haas H (2000) xylP promoter-based expression system and its use for antisense downregulation of the Penicillium chrysogenum nitrogen regulator NRE. Appl Environ Microbiol 66(11):4810-4816

Zhang G, Liu P, Wei W, Wang X, Wei D, Wang W (2016) A lightswitchable bidirectional expression system in filamentous fungus Trichoderma reesei. J Biotechnol 240:85-93. https://doi.org/10. 1016/j.jbiotec.2016.11.003

Zhiwei Y, Zhuhua C, Fan Y, Yang L, Runying Z (2015) Optimization of cold-active lipase production by CALIP1 from deep-sea sedimentderived metagenomic library. Res J Biotechnol 10(4):91-97

Zubieta MP, Contesini FJ, Rubio MV, Gonçalves A, Gerhardt JA, Prade RA, Damasio ARL (2018) Protein profile in Aspergillus nidulans recombinant strains overproducing heterologous enzymes. Microb Biotechnol 11(2):346-358. https://doi.org/10.1111/1751-7915. 13027 